\title{
PERANCANGAN SISTEM KERJA UNTUK MENINGKATKAN HASIL PRODUKSI MELALUI PENDEKATAN MACROERGONOMIC ANALYSIS AND DESIGN DI SENTRA INDUSTRI BATIK AYU ARIMBI SLEMAN
}

\author{
Trismi Ristyowati ${ }^{1}$ dan Tri Wibawa ${ }^{2}$ \\ $1 \&$ 2. Jurusan Teknik Industri Fakultas Teknik Industri \\ UPN "Veteran” Yogyakarta \\ Email :trismi_ristyowati@yahoo.com
}

\begin{abstract}
ABSTRAK
Sentra Batik Ayu Arimbi yang ada di daerah Plalangan, Pandowoharjo, Kabupaten Sleman, Yogyakarta adalah sebuah Sentra batik yang menggunakan pewarna alam sebagai pewarna batik dan masih menggunakan cara-cara tradisional dalam sistem kerjanya. Pekerja di sana sering mengalami kelelahan khususnya dalam membuat pola batik, serta waktu yang dibutuhkan dalam membuat pola batik masih terlalu lama. Hal ini disebabkan tidak adanya fasilitas alat bantu untuk pembuatan pola batik. Untuk itu perlu dirancang meja batik tulis yang efesien, nyaman, aman dan mudah dalam proses penggunaan dan perawatannya. Dalam penelitian ini pengidentifikasian permasalahan dengan pendekatan Macroergonomic Analisys and Design (MEAD).

Langkah penelitian diawali dengan menganalisis faktor kunci dalam makroergonomi, kemudian mencari solusi atas variansi yang terjadi pada faktor kunci tersebut. Berdasarkan analisis tempat kerja diperoleh bahwa bidang teknologi dan fasilitas kerja menjadi faktor kunci, maka dirancanglah alat bantu meja pola batik. Kemudian perancangan meja pola batik secara ergonomis dengan memperhatikan atribut meliputi meja pola batik yang nyaman saat digunakan, meja mudah dioperasikan, pola dasar batik terlihat jelas, pola batik yang memiliki kualitas lebih baik, pekerja tidak cepat lelah, dan meja pola batik yang perawatannya mudah. Pengujian meja pola batik dilakukan secara kuantitatif dan kualitatif dengan melibatkan pengguna dan ketua sentra.

Hasil penelitian menunjukkan bahwa meja pola batik yang dirancang dapat menurunkan keluhan pembuat pola batik dan pekerjaan dilakukan secara ergonomis. Secara kualitatif hasil produksi design batik lebih tajam dan indah, kuesioner menunjukan bahwa meja pola batik mudah dioperasikan, nyaman pada saat digunakan, dan mudah dalam melakukan perawatan. Secara Kuantitatif dapat meningkatkan jumlah roduksi, dikarenakan waktu proses menggambar pola yang semula 18 jam menjadi 6 jam, waktu yang dapat dihemat adalah 2 hari kerja.
\end{abstract}

\section{Kata Kunci : perancangan, Macroergonomic, kelelahan, kualitatif, kuantitatif}

\section{PENDAhuluan}

Sentra industri batik Ayu Arimbi berada di Padukuhan Plalangan Gajah Kuning, Desa Pandowoharjo, Kecamatan Sleman, Kabupaten Sleman. Sentra ini ketua oleh Ibu Tatik Susilowati, dengan anggota sebanyak 18 pengrajin. Secara umum, para pengrajin terdiri dari ibu-ibu rumah tangga. Produk yang dihasilkan berupa batik cap dan batik tulis. Ciri khas yang dikembangkan dan menjadi daya saing industri batik ini adalah bahwa batik yang

Hasil survei dan pengamatan di Sentra Industri Batik Ayu Arimbi menunjukkan bahwa proses produksi masih dilakukan secara sederhana. Diawali dari penyiapan bahan kain, membuat pola, dan membatik dengan tangan dan cap. Selanjutnya penjemuran, pencelupan, dan pengeringan. Peralatan yang digunakan diproduksi dengan motif khas sinom parijoto dengan kombinasi salak. Selain itu penggunaan kombinasi warna sintetis dan pewarna alami yang ramah lingkungan. Bahan baku dan bahan pendukung yang digunakan antara lain adalah kain, lilin/malam, pewarna alami, pewarna sintetis, kuas, canting, $\mathrm{HCl}$, dan Asam Nitrit. Bahan baku kain dari PT Primissima, Medari, Sleman, sedangkan bahan lainnya dari Pemasok Bantul dan Klaten. untuk mendukung proses produksi diantaranya adalah kompor, canting, cap tangan, dan kuas. Kelemahan yang dihadapi ditinjau dari lingkungan kerjanya masih banyak yang harus diperbaiki. Berdasarkan aspek pemodalan dan finansial, sumber modal usaha berasal dari modal pribadi, pinjaman, dan bantuan 
pemerintah. Penghasilan yang diterima pengrajin tergantung dari besarnya produk yang terjual. Sistem administrasi yang diterapkan oleh sentra ini masih bersifat tradisional dengan cara manual dituliskan dalam buku khas.

\section{LANDASAN TEORI}

Sistem kerja merupakan rangkaian tata kerja dan prosedur kerja yang kemudian membentuk suatu kebulatan pola tertentu dalam rangka melaksanakan suatu bidang pekerjaan (KBBI, 2005). Menurut Kleiner (2006), sistem kerja terdiri dari dua atau lebih orang yang bekerja bersama-sama (personel sub-sistem), berinteraksi dengan teknologi (technological sub-system) dalam sistem organisasi yang dicirikan oleh lingkungan internal (both physical and cultural). Menurut Freivald (2010), elemen-elemen sistem kerja terdiri dari organisasi, human, tasks, environment, dan tools/teknologi.

Menurut Kleiner (2006), sistem kerja terdiri dari dua atau lebih orang yang bekerja bersama-sama (personel sub-sistem), berinteraksi dengan teknologi (technological sub-system) dalam sistem organisasi yang dicirikan oleh lingkungan internal (both physical and cultural). Sistem kerja yang ada pada suatu perusahaan akan mempengaruhi jalannya produksi, oleh karenanya pengaturan sistem kerja yang baik sangat diperlukan bagi setiap perusahaan sebagai faktor penting dalam meningkatkan produktivitas kerja.

Batik adalah karya budaya yang merupakan warisan nenek moyang dan memiliki nilai seni yang tinggi, dengan corak,

\section{METODOLOGI PENELITIAN}

Penelitian dilakukan di sentra industri batik Ayu Arimbi Sleman. Obyek yang menjadi fokus penelitian ini adalah mengevaluasi sistem kerja yang meliputi faktor organisasi, peralatan, pekerjaan dan lingkungan fisik. Pada keempat faktor tersebut akan dicari faktor kunci yang mempengaruhi kenyamanan pekerja dan produktivtas sehingga dapat dibuat usulan perbaikan sistem kerja.

Berdasarkan hasil pengamatan dan wawancara terhadap karyawan pada sentra batik Ayu Arimbi terdapat permasalahan pada keluhan kenyamanan pekerja pada saat proses produksi terutama pada saat pembuatan pola batik tulis. Pada sentra batik ini proses pembuatan pola dilakukan secara manual dengan cara yang tidak ergonomis yaitu dengan serta tata warna yang khas milik suatu daerah yang menunjukkan identitas bangsa Indonesia. Batik sebagai asset budaya merupakan ikon produk Indonesia yang memiliki nilai historis dan memiliki citra ekslusif yang menggambarkan status pemakainya.

Berdasarkan latar belakang yang diuraikan di atas, permasalahan dalam penelitian ini adalah bagaimana merancang sistem kerja yang aman, nyaman, efektif, dan efisien sesuai kaidah ergonomi sehingga akan meningkatkan kualitas dan kuantitas hasil produksi di Sentra Batik Ayu Arimbi dengan pendekatan macroergonomic analysis and design. Tujuan yang hendak dicapai dalam penelitian ini adalah sebagai berikut :

1) Merancang sistem kerja di Sentra Batik Ayu Arimbi dengan pendekatan macroergonomic analysis and design.

2) Mengetahui kenyamanan kerja karyawan sebelum dan sesudah perancangan.

3) Mengetahui output produk yang dibuat untuk mengukur produktivitas hasil perancangan.

Manfaat yang diharapkan dari hasil penelitian ini adalah sebagai berikut :

1) Industri kecil dan menengah dapat mengenal dan menerapkan teknologi untuk meningkatkan produktivitasnya.

2) Sebagai bahan pertimbangan untuk melakukan perbaikan terhadap sistem kerja dengan sehat, aman, nyaman, efektif dan efisien.

3) Salah satu penerapan difusi teknologi dari akademisi ke dalam masyarakat.

duduk dilantai selama 1 jam membuat pola selanjutnya beristirahat sebentar lalu melanjutkan lagi membuat pola 1 jam dan seterusnya, sehingga satu kain batik tulis membutuhkan waktu selama 18 jam dalam satu pola kain batik tulis. Posisi kerja seperti ini tentunya berisiko menimbulkan keluhankeluhan pada sistem musculoskeletal. Sedangkan keluhan dari pekerja yang mengalami rasa sakit ketika selesai beraktivitas seharian di industri tersebut, rata-rata pekerja memiliki keluhan yang sama yaitu kaki kesemutan, pegal-pegal pada leher, tangan dan tulang belakang karena terlalu lama duduk bersila di lantai. Identifikasi postur kerja yang tidak aman bagi tubuh yang dapat menimbulkan gejala Musculosketal Disorders (MSDs). 
Dalam mengatasi kondisi sistem kerja
yang belum optimal digunakan Macroergonomic Analysis and Design (MEAD) untuk mengevaluasi sistem kerja pada Industri Batik Ayu Arimbi sehingga dapat diketahui faktor kunci dalam sistem kerja yang paling berpengaruh terhadap produktivitas dan dapat dibuat usulan perbaikan berdasarkan faktor kunci yang terpilih sehingga dapat memperbaiki sistem kerja menjadi lebih baik. Macroergonomic Analysis and Design (MEAD) merupakan metodologi yang menggambarkan tahapan implementasi ergonomi makro yang dapat digunakan untuk mengevaluasi dan merancang sistem kerja. Kerangka umum Macroergonomic Analysis and Design (MEAD) dikembangkan oleh Emery and Trist (1978) dalam Hendrick and Kleiner (2001). Berikut ini adalah penjabaran dari langkah pengolahan data yang dilakukan:

1. Mengamati sistem organisasi secara internal dan eksternal

4. Mengidentifikasi variansi yang terjadi Identifikasi varian berdasarkan keempat faktor dalam sistem kerja yang telah diperoleh dari wawancara, observasi, pengukuran dan langkah-langkah sebelumnya. Identifikasi data varian dilakukan dengan kuesioner yang dibagikan kepada 20 pekerja. Data yang diperoleh dari kuesioner selanjutnya dihitung prosentase jawaban responden untuk mengetahui permasalahan yang dihadapi. Tujuan pada tahap ini adalah untuk mengetahui permasalahanpermasalahan yang terjadi sekaligus untuk mempermudah pada proses pengolahan data selanjutnya.

5. Membuat matriks variansi

Dari varian yang ada pada tahap sebelumnya akan diperoleh varian yang yang menjadi faktor kunci, varian yang memberi dampak signifikan pada kriteria peformansi atau hubungannya dengan varian lain. Matriks varian bertujuan untuk mengetahui hubungan keterkaitan antar varian dan pengaruh varian satu dengan varian lainnya. Pengisia matriks varian berdasarkan wawancara dengan pekerja.

6. Membuat tabel kendali variansi kunci dan jaringan peran

Pada tahap ini bertujuan untuk mengetahui peran personel dan tanggung jawabnya
Pengamatan dilakukan secara internal dan eksternal, berdasarkan hasil pengamatan maka dapat diidentifikasi visi, misi, struktur organisasi, sistem kerja serta lingkungan kerja yang ada. Pengidentifikasi varian juga sudah mulai dilakukan pada tahap ini dalam lingkungan fisik kerja dan organisasi.

2. Mendefinisikan tipe sistem operasi kerja dan ekspektasi kerja

Dengan mempertimbangkan aspek komplesksitas, formalisasi dan sentralisasi organisasi kerja akan diperoleh kondisi optimal rancangan sistem operasi kerja. Dan penentuan kriteria kesuksesan produksi dilakukan dengan mengambil tujuh kriteria, yitu efisiensi, efektivitas, produktivitas, kualitas, kualitas kehidupan kerja, inovasi dan keuntungan.

3. Mendefinisikan unit operasi dan proses kerja Identifikasi unit operasi dan proses kerja yang ada di Sentra Ayam Goreng Kalasan. Identifikasi juga dilakukan terhadap varian yang ada pada faktor kondisi pekerjaan.

serta bagaimana kendali varian yang terjadi dan pihak yang bertanggung jawab untuk hal tersebut. Tabel kendali variansi kunci sendiri terdiri atas varian pada faktir kunci, unit kerja atau tempat terjadinya, siapa orang yang bertanggung jawab, tools atau teknologi yang diperlukan untuk mendukung pengendalian, serta kemampuan khusus atau pengetahuan yang dibutuhkan dalam pengendalian variansi kunci tersebut.

7. Menunjukkan alokasi fungsi dan rancangan bersama

Melakukan perbaikan berdasarkan variansi terbesar. Alokasi fungsi dan rancangan bersama untuk perbaikan dibuat berdasarkan tabel kendali varian dan varian kunci.

8. Memahami persepsi mengenai peran dan tanggug jawab

Mengidentifikasi pengetahuan atau kemampuan yang dibutuhkan personel yang bertanggung jawab di tempat terjadi penyimpangan. Selain itu juga mengidentifikasi serta mengevaluasi persepsi dan tanggung jawab personel tersebut terhadap tugas serta apa yang telah dikerjakan sehingga akan diperoleh aturan kerja yang sesuai.

9. Merancang atau memperbaiki subsistem pendukung dan interface 
Membuat rancangan perbaikan sistem kerja dari alternative yang telah dibuat agar

Macroergonomic Analysis and Design (MEAD) yang terdiri dari 10 fase. Langkah atau tahapan proses Macroergonomic Analysis and Design (MEAD) tersebut dapat digunakan untuk mengevaluasi dan merancang sistem kerja.

\section{Identifikasi lingkungan dan subsistem organisasi}

Analisis visi, misi, dan asas dasar organisasi. Misi menjelaskan tentang tujuan organisasi dan aktivitas produksi/pelayanan. Visi merupakan pandangan ke depan yang akan dicapai organisasi pada jangka 5-10 tahun. Asas dasar merupakan elemen-elemen kultural yang mendefinisikan atribut inti organisasi. Visi sentra industri batik Ayu Arimbi adalah menjadi sentra batik yang maju dan dikenal di seluruh dunia. Menganalisis tinjauan aspek lingkungan. Lingkungan meliputi lingkungan fisik yang berupa kenyamanan, sensorik, dan gangguan kinerja, dan lingkungan sosial yang berupa interaksi dengan rekan kerja/atasan dan dukungan sosial

2. Mendefinisikan jenis sistem produksi dan ekspektasi performansi

Tipe sistem produksi dan kriteria ekspektasi didefinisikan dalam langkah ini. Kriteria ekspektasi performansi berhubungan dengan tujuan organisasi dan teknikal proses yang ada. Tipe produksi didasarkan pada make to order (pembuatan berdasarkan pesanan). Ada beberapa batik tulis khas juga dibuat untuk keperluan khusus seperti promosi dan pameran. sesuai dengan keinginan dan harapan dari pemilik dan pekerja.

\section{HASIL DAN PEMBAHASAN}

\section{Mengidentifikasi data varian}

Identifikasi data varian bertujuan untuk mengetahui permasalahan yang ada sehingga dapat memudahkan proses analisis selanjutnya. Faktor-faktor yang menimbulkan varian (lingkungan fisik, peralatan/mesin, kondisi pengrajinan, dan organisasi) dan varian yang terjadi sudah diidentifikasi pada langkah sebelumnya. Setelah dilakukan perhitungan prosentase dari jawaban seluruh responden, dapat diidentifikasi data varian yang dapat dilihat pada Tabel 1.

\section{Membuat matriks varian}

Matriks varian bertujuan untuk mengetahui hubungan atau keterkaitan antar varian atau apakah varian yang satu mempengaruhi varian lainnya. Pengisian matriks varian berdasarkan wawancara dengan pengrajin. Matriks varian dapat dilihat pada Lampiran B. Varian yang memiliki hubungan/keterkaitan diberi simbol (X) pada sel pertemuan kedua varian tersebut. Dari matriks varian yang telah dibuat diperoleh bahwa beberapa varian memiliki banyak keterkaitan dengan varian lain. Faktor yang variannya memiliki keterkaitan atau hubungan paling banyak dengan varian lain akan menjadi faktor kunci. Tanda hubungan antar varian yang dicetak tebal merupakan faktor kunci karena memiliki keterkaitan paling banyak dengan varian lain. Faktor kunci terpilih dapat dilihat pada Tabel 2.

Tabel 1. Data varian

\begin{tabular}{|c|c|c|}
\hline No & Faktor & Varian \\
\hline \multirow{6}{*}{1} & \multirow{6}{*}{ Organisasi } & Bimbingan kerja \\
\hline & & Koordinasi \\
\hline & & Kesulitan dalam komunikasi \\
\hline & & Konflik saat kerja \\
\hline & & Pengambilan keputusan \\
\hline & & Reward \\
\hline \multirow{2}{*}{2} & \multirow{2}{*}{ Teknologi } & Kesesuaian alat kerja \\
\hline & & Masalah desain alat kerja \\
\hline \multirow{6}{*}{3} & \multirow{6}{*}{ Personal } & Perasaan pada organisasi \\
\hline & & Perasaan ada diri sendiri \\
\hline & & Penilaian terhadap rekan kerja \\
\hline & & Pembagian kerja \\
\hline & & Jam kerja \\
\hline & & Pekerjaan yang dilakukan \\
\hline
\end{tabular}




\begin{tabular}{|l|l|l|}
\hline No & \multicolumn{1}{|c|}{ Faktor } & \multicolumn{1}{c|}{ Varian } \\
\hline \multirow{4}{*}{4} & & Kelelahan kerja \\
\cline { 3 - 3 } & & Budaya kerja \\
\cline { 3 - 3 } & \multirow{4}{*}{ Lingkungan } & Kehadiran \\
\hline & & Lingkungan kerja \\
\cline { 3 - 3 } & & Tata letak fasilitas \\
\cline { 3 - 3 } & & Pencahayaan \\
\cline { 3 - 3 } & & Kondisi suhu \\
\hline
\end{tabular}

Tabel 2. Faktor kunci yang mempengaruhi sistem kerja

\begin{tabular}{|l|l|}
\hline Faktor kunci & Varian \\
\hline \multirow{2}{*}{ Teknologi } & Kesesuaian alat kerja \\
\cline { 2 - 2 } & Masalah alat kerja \\
\hline
\end{tabular}

\section{Membuat tabel kendali varian kunci dan jaringan peran}

Tahap ini bertujuan untuk mengetahui bagaimana kendali atau kontrol varian yang telah ada dan bagaimana peran personel yang bertanggung jawab di perusahaan. Penyusunan tabel kendali varian kunci dan jaringan peran berdasarkan identifikasi faktor kunci yang terpilih pada langkah sebelumnya, faktor kunci yang terpilih yaitu lingkungan fisik yang berupa suhu ruang kerja yang panas dan kebisingan di tempat kerja.

\section{Penyusunan fuction alocation and joint design}

Tahap ini bertujuan untuk membuat fungsi alokasi dan rancangan alternatif perbaikan dari tabel kendali varian dan varian kunci yang ada dalam bentuk objectivelactivity tree. Alternatif pertama yang bisa dilakukan adalah pengadaan fasilitas peralatan pendukung teknologi. Alternatif kedua mengembangkan budaya organisasi yang lebih efektif, nyaman, aman, dan efisien.

Dari hasil identifikasi faktor kunci diperoleh hasil bahwa subsistem lingkungan dan subsistem organisasi pada Industri Batik Ayu Arimbi Sleman. Kondisi lingkungan fisik kerja yang dikeluhkan meliputi suhu, kebisingan, dan cahaya. Sedangkan kondisi organisasi yang dikeluhkan pekerja meliputi kesejahteraan, pembagian kerja, dan perhatian pimpinan terhadap keadaan pekerja dan lingkungan fisik kerja. Untuk mencapai ekspektasi performansi yang diinginkan, tidak terlepas dari peralatan dan mesin yang digunakan. Kondisi peralatan dan mesin masih terdapat kekurangan berdasarkan keluhan dari pekerja yaitu mengenai kurangnya peralatan dan tenaga pembimbing ahli.

Identifikasi data varian bertujuan untuk mengetahui permasalahan yang ada sehingga dapat memudahkan proses analisis selanjutnya. Faktor-faktor yang menimbulkan varian (lingkungan fisik, peralatan/mesin, kondisi pekerjaan, dan organisasi) dan varian yang terjadi sudah diidentifikasi pada langkah sebelumnya. Untuk memperoleh data varian yang lebih rinci dilakukan penyebaran kuesioner pada seluruh pekerja bagian produksi sehingga dapat diketahui permasalahan yang dihadapi seluruh pekerja bagian produksi. Setelah dilakukan perhitungan prosentase dari jawaban seluruh responden, dapat diidentifikasi data varian terpilih adalah fasilitas lingkungan fisik dan pengaturan jam kerja. Matriks varian bertujuan untuk mengetahui hubungan atau keterkaitan antar varian atau apakah varian yang satu mempengaruhi varian lainnya. Faktor yang variannya memiliki keterkaitan atau hubungan paling banyak dengan varian lain akan menjadi faktor kunci. Faktor kunci terpilih adalah faktor peralatan yang belum mendukung kenyamanan kerja.

Penyusunan function allocation and joint design. Tahap ini bertujuan untuk membuat fungsi alokasi dan rancangan alternatif perbaikan dari tabel kendali varian dan varian kunci yang ada dalam bentuk objectives/activity tree. Rancangan alternatif yang ada dapat dilihat pada Gambar 1. Selanjutnya dilakukan evaluasi peran dan persepsi tanggungjawab. Pada tahap ini bertujuan untuk memberikan pembobotan untuk masing-masing alternatif perbaikan sehingga dapat diperoleh alternatif yang baik dan dapat diterapkan. Penilaian 
pembobotan dilakukan secara subyektif kriteria yang memiliki keterkaitan dengan alternatif.

Perancangan ulang subsistem pendukung bertujuan untuk membuat rancangan perbaikan pada subsistem yang dapat memperbaiki sistem kerja menjadi lebih baik sehingga produktivitas dapat ditingkatkan. Faktor kunci yang terpilih yaitu faktor peralatan kerja. Proses perancangan pada fase ini dilakukan dengan mewujudkan konsep yang dipilih menjadi wujud nyata, uraian mengenai perancangan wujud tersebut dengan membuat gambar rancangan 3D dapat dilihat pada Gambar 2.

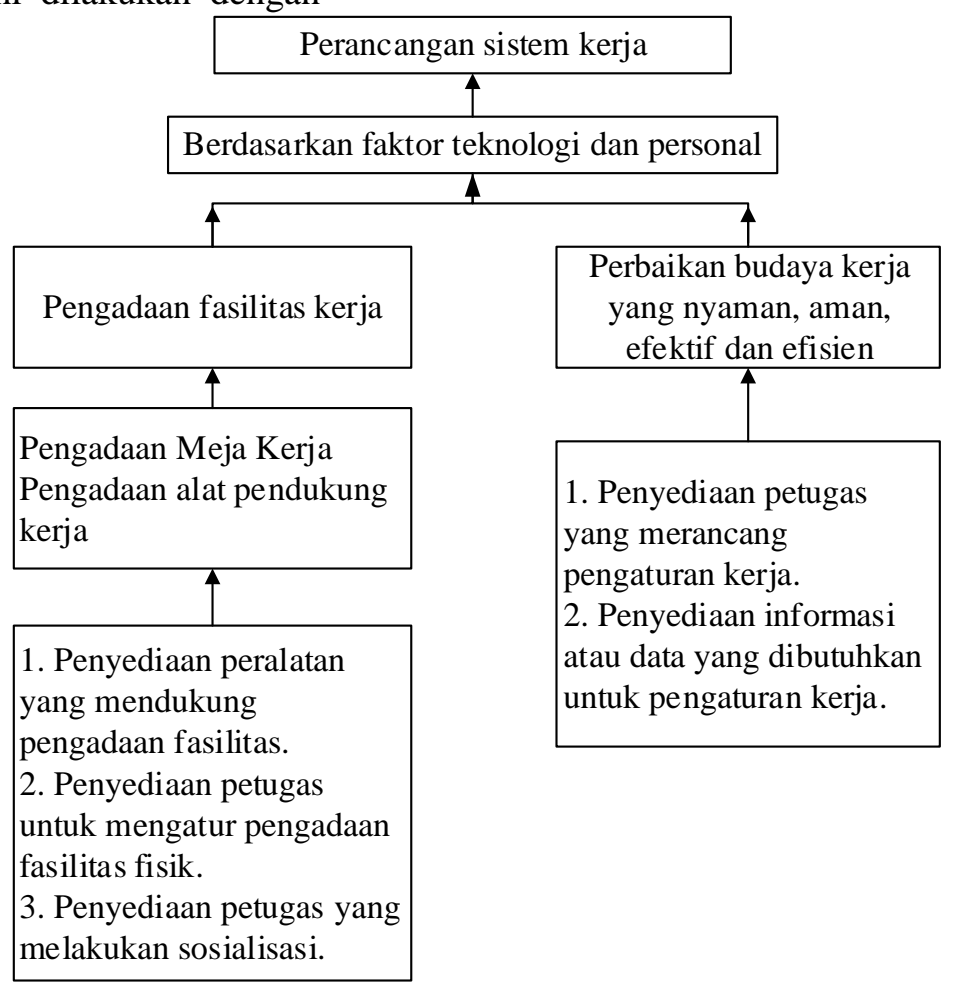

Gambar 1. Objectives/activity tree

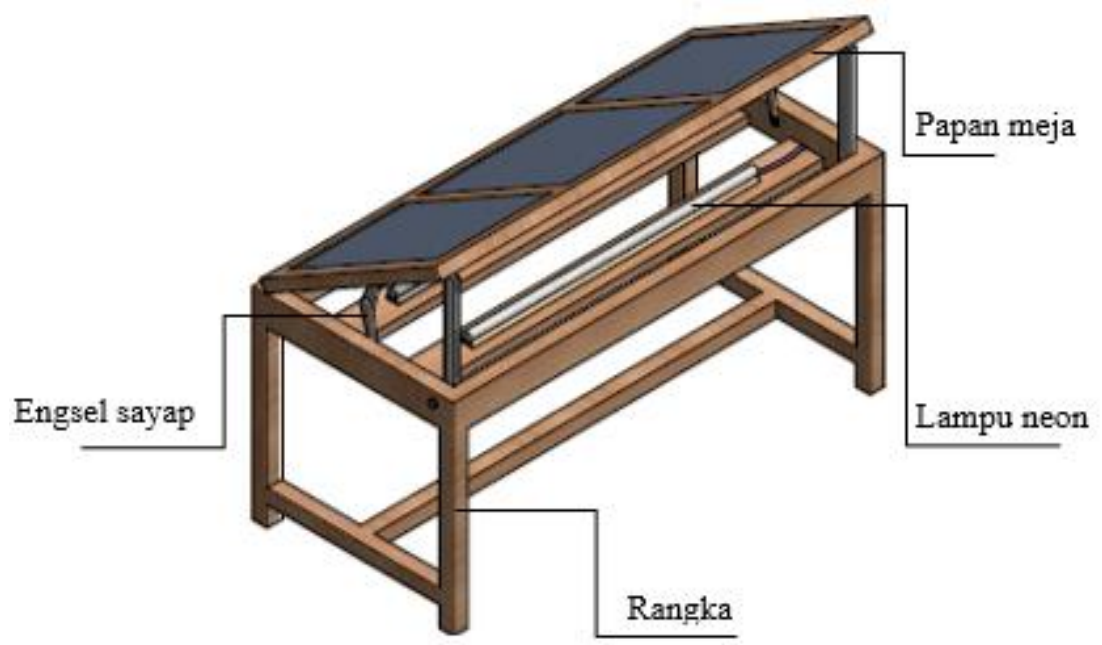

Gambar 2. Meja pola batik tulis 3D

Uji kelelahan secara subjektif dilakukan dengan penyebaran kuesioner terhadap pekerja di sentra batik Ayu Arimbi.
Kuesioner disebarkan kepada 4 responden diantaranya terdapat 3 pekerja dan 1 ketua sentra. Perhitungan skala likert dimulai untuk 
menghitung skor jawaban ditunjukkan pada

Tabel 3 dan Tabel 4.

Tabel 3. Hasil kuesioner tingkat kelelahan fisik

\begin{tabular}{|c|c|c|c|}
\hline No & Jenis Kelelahan & $\begin{array}{l}\text { Skala } \\
\text { likert }\end{array}$ & Keterangan \\
\hline 1 & Sakit kepala & 4 & \multirow{11}{*}{$\begin{array}{l}3,85 \text { artinya sebagian } \\
\text { besar responden } \\
\text { mengalami penurunan } \\
\text { kelelahan fisik. }\end{array}$} \\
\hline 2 & Kekakuan di bahu & 3,75 & \\
\hline 3 & Merasa nyeri di bagian belakang kepala & 3,75 & \\
\hline 4 & Merasa pening & 4 & \\
\hline 5 & Spasme (kaku) di kelopak mata & 4 & \\
\hline 6 & Tremor(gemetar) anggota badan & 4 & \\
\hline 7 & Merasa kurang sehat & 4 & \\
\hline 8 & Haus & 3,5 & \\
\hline 9 & Merasa pernafasan tertekan & 4 & \\
\hline 10 & Merasa nyeri di punggung & 3,5 & \\
\hline & Rata-rata & $\mathbf{3 , 8 5}$ & \\
\hline
\end{tabular}

Tabel 4. Hasil kuesioner tingkat kepuasan

\begin{tabular}{|c|c|c|}
\hline $\begin{array}{l}\text { Jenis } \\
\text { pertanyaan }\end{array}$ & $\begin{array}{l}\text { Skala } \\
\text { likert }\end{array}$ & Keterangan \\
\hline $\begin{array}{l}\text { Pengoprasian } \\
\text { meja }\end{array}$ & 4,5 & $\begin{array}{l}4,5 \text { artinya sebagian besar responden mudah dalam } \\
\text { pengoperasian meja batik tulis.. }\end{array}$ \\
\hline $\begin{array}{l}\text { Kenyamanan } \\
\text { meja }\end{array}$ & 4,75 & $\begin{array}{l}4,75 \text { artinya sebagian besar responden nyaman } \\
\text { memakai meja batik tulis.. }\end{array}$ \\
\hline Perawatan meja & 4,75 & $\begin{array}{l}4,75 \text { artinya sebagian besar responden mudah dalam } \\
\text { merawat meja batik tulis.. }\end{array}$ \\
\hline
\end{tabular}

Perancangan meja batik tulis untuk perancangan dan penjelasan tugas adalah dapat menentukan kriteria yang diinginkan Sentra Batik Ayu Arimbi. Kriteria yang diinginkan yaitu mengurangi kelelahan serta kenyamanan pekerja, mengurangi waktu setup, mudah dalam pengoperasian meja batik tulis, dan mudah dalam melakukan perawatan. Hasil yang didapatkan dalam perancangan dan penjelasan tugas akan dijadikan konsep untuk perancangan meja batik tulis. Hasil dari penelitian menunjukan bahwa waktu proses yang dihasilkan sebelum memakai meja batik membutuhkan 18 jam untuk membuat pola dalam satu kain batik. Hal ini menunjukan bahwa masih belum efektif. Sedangkan hasil dari meja pola batik memerlukan waktu sebesar 6 jam untuk membuat pola batik dalam 1 kain

\section{KESIMPULAN}

Berdasarkan hasil analisis hasil dan pembahasan penerapan MEAD di Sentra Batik Ayu Arimbi, maka dapat disimpulkan sebagai berikut:

1. Faktor kunci yang mempengaruhi sistem kerja untuk meningkatkan produktivitas adalah faktor teknologi yang terdiri dari batik. Sehingga meja batik tulis dapat meningkatkan waktu proses produksi pada Sentra Batik Ayu Arimbi.

Hasil pengujian untuk uji kelelahan secara objektif sebelum memakai meja batik dapat diketahui pada Tabel 1 memilki rata-rata sebesar $39,03 \%$. Setelah menggunakan meja batik dapat di ketahui pada Tabel 2 memiliki rata-rata sebesar 30,69\%. Hasil dari perhitungan menunjukan bahwa menggunakan meja batik memiliki angka rata-rata yang lebih rendah dibandingkan dengan tidak menggunakan meja dengan selisih rata-rata sebesar $8,34 \%$ menunjukan tidak terjadi kelelahan. Kelelahan fisik dengan hasil ratarata 3,85 yang berarti rendahnya tingkat kelelahan fisik terhadap sebagian besar responden.

varian keseusaian alat kerja dan masalah desain peralatan kerja

2. Perbaikan sistem kerja dilakukan dengan pengadaan peralatan kerja berupa meja pola batik, sosialisasi penggunaan meja batik yang baik dan benar yang dapat dilakukan pada saat breifing sebelum mulai kerja.. 
3. Waktu proses pembuatan pola batik dengan meja kerja semakin cepat 6 jam dibanding dengan sistem kerja lama yang prosesnya sampai $18 \mathrm{jam}$.

\section{DAFTAR PUSTAKA}

Adiatmika, I.P.G, 2006, Modifikasi Meja Kerja Menurunkan Beban Kerja Karyawan Kerajinan Logam di Kabupaten Tabanan Bali, Prosiding Seminar Nasional dan Kongres Ergonomi III, Teknik Industri, Universitas Trisakti, Jakarta

Andewi, P.J, 1999, Perbaikan Sikap Kerja dengan Memakai Kursi dan Meja Kerja yang Sesuai dengan Data Antropometri Pekerja dapat Meningkatkan Produktivitas Kerja dan Mengurangi Gangguan sistem Musculoskeletal, Thesis Magister, Pascasarjana Universitas Udayana, Denpasar, Bali

Adiputra, N., Sutjana, D.P., Widana, K., Manuaba, A., O'Neill. (1997). Participatory Ergonomics in Agriculture, Case Study in Batunya Village Bali, Indonesia. In: Khalid, H.M. editor. Proceeding of $5^{\text {th }}$ SEAES Conference, 6-7 Nov. Kualalumpur: IEA Press. p. 463-467

Anonim, 2015, Peraturan Presiden Republik Indonesia Nomor 72 Tahun 2015, tentang Perubahan Atas Peraturan Presiden Nomor 6 Tahun 2015 tentang Badan Ekonomi Kreatif, 16 Juni 2015.

Grandjean, E, \& Kroemer, 2000, Fitting the Task to the Human, A textbook of Occupational Ergonomics, 5th edition,Taylor\&Francis, Piladelphie.

Gupta, N.K., K. Diallo, P. Zurn, M.R. Dal Poz, 2003, Assessing Human Resources for Healt : What can be learan from labour force survey?, Human Resources Health. 1(1):5.

Hendra \& R. Suwandi, 2009, Risiko Ergonomi Dan Keluhan Musculoskeletal Disorders (MSDs) Pada Pekerja Panen Kelapa Sawit, Prosiding Seminar Nasional IX dan Kongres Ergonomi IV, Teknik Industri, Universitas Diponegoro, Semarang, Jawa Tengah.

Hendrick, H. W. and Kleiner, B. M., 2001, Macroergonomics: An Introduction To Work System Design, HFES Publisher.,Santa Monica- USA.

Iridiastadi, H. dan Yassierli, 2014, Ergonomi Suatu Pengantar, Cetakan Pertama, PT Remaja Rosdakarya, Bandung.
Brian M. K, (2002). Computer-Aided Macroergonomics for Improved Performance and Safety. Human Factors and Ergonomics in Manufacturing, Wiley Periodicals, Inc. Published online in Wiley InterScience.www.interscience.wiley.com Vol. 12 (3) 307-319

Dewi, C, 2009, Analisis Potensi Resiko Cedera Musculoskeletal dan Usaha Perbaikan dari Resiko Cedera Musculoskeletal (Studi Kasus pada Pekerja Pembuat Tali Pandan di Industri Kecil Desa Tanjung Harjo, Nanggulan, Yogyakarta), Prosiding Seminar Nasional IX dan Kongres Ergonomi IV, Teknik Industri, Universitas Diponegoro, Semarang, Jawa Tengah

Erensal, Y.C, Albayrak. (2004). Successful Adoption of Macroergonomics in Manufacturing: Using a Multicriteria Decision-Making Methodology-Analytic Hierarchy Process. Human Factors and Ergonomics in Manufacturing. Wiley Periodicals, Inc. Published online in Wiley InterScience.www.interscience.wiley.com vol. 14 (4) 353-377.

Evanof, B. A., Bohr, P. C. and Wolf, L. D. (1999). Effect of a Participatory Ergonomic Team Among Hospital Onderlies. American Journal of Industrial Medicine. 35: 558-365

Jeppesen, H. J. (2003). Participatory Aproaches to Strategy and Research in Shift Work Intervention. Theoretical and Issues in Ergonomic. $4(3,4)$ : 289 - 301.

Kleiner, B. M., 2006, Macroergonomics: Analysis and design of work system design, Applied Ergonomics, 37, 81-89.

Kawakami, T., Kogi, K., Toyoma, N. and Yoshikawa, T. (2004). Participatory Approaches to Improving Safety and Health Under Trade Union Initiative. Industrial Health. 42: 196-206

Laing, A.C., Frazer, B.M, Cole, D.C., Kerr, M.S., Well, R.P. and Norman, R.W. (2005). Study of the effectiveness of a participatory ergonomic intervention in reducing worker pain severity through physical exposure pathways. International journal of ergonomic, 48 (2,2):150-170.

Lucitasari, D.R., \& Wibawa, T, 2016, Strategi Pengembangan Industri Batik Kayu Krebet Pajangan Bantul dengan Pendekatan Macroergonomic Analysis 
and Design, Laporan Penelitian Terapan, LPPM UPN "Veteran" Yogyakarta

McCormick,E.J. \& Sanders,M.S., 1993, Human Factor in Engineering and Design, $7^{\text {th }}$ edition, McGraw-Hill Inc.

Manuaba, A, 1998a, Bunga rampai Ergonomi, Vol. II, Program studi Ergonomi dan Fisiologi Kerja, Universitas Udayana, Denpasar.

Manuaba, A. (1999). Penerapan Ergonomi Partisipasi dalam Meningkatkan Kinerja Industri. Makalah. Disampaikan pada Seminar Nasional Ergonomi, Reevaluasi Penerapan Ergonomi dalam Meningkatkan Kinerja Industri. Surabaya 23 Nopember.

Manuaba, A. (2003). Penerapan Ergonomi Meningkatkan Produktivitas. Makalah. Denpasar: Bagian Ilmu Faal Fakultas Kedokteran Universitas Udayana.

Nagamachi, M. (1995). Requisites and practice of participatory ergonomic. International Journal of Industrial Ergonomics, 15(5): 371-377

Netrawati, IGA, S. Hadi, Tarwaka, 2001, Sarana Kerja yang tidak Ergonomis Meningkatkan Musculoskeletal pada
Pekerja Garmen di Bali, Prosiding Seminar Nasional XII, Ikatan Ahli Faal Indonesia, Malang.

Niebel, B. \& A. Freivalds, 2003, Methods, Standards, and Work Design, $11^{\text {th }}$ Edition, McGraw-Hill Series, Singapore.

Nurmianto, E., 2004, Ergonomi Konsep Dasar Dan Aplikasinya, Edisi kedua, Penerbit Guna Widya, Surabaya.

Robertson, M. M. Amick, B. C., Hupert, N., Pellerin-Dionne. M., Cha, E. and Katz, J. N. 2002. Effect of a Participatory Computer Workshop for University Student: A Pilot Intervention to Present disability in Tomorrow's Workers. Scan J Work Environ Health. USA: IOS Press. p. 305-314.

Sutalaksana,I.Z., Anggawisastra,R., dan Tjakraatmadja,J.H.,1979, Teknik Tata Cara Kerja, Jurusan Teknik Industri ITB, Bandung.

Wibawa, T, 2009, Perancangan Stasiun Kerja pada Industri Emping Melinjo dengan Pendekatan Human Centered Design (HCD), Jurnal Optimasi Sistem Industri, Teknik Industri, UPN "Veteran" Yogyakarta (dalam proses penerbitan). 